\title{
Capital market, financial deepening and Nigeria's economic growth: empirical evidence
}

\author{
Raymond Osi Alenoghena $\mathrm{a}^{*}$ \\ a Department of Economics, Faculty of Social Sciences, University of Lagos, Nigeria \\ ${ }^{*}$ Corresponding author's e-mail: raymondalen@hotmail.com
}

H I G H L I G H T S:

1. The study investigates the impact of capital market and financially deepening to economic growth in Nigeria.

2. The window of analysis is from 1981-2012.

3. The results from error correction model suggest that financial deepening has significant effect on the economic growth of Nigeria.

4. The result supports policy of government and other stakeholders to improve the liquidity of the financial market to enhance overall economic efficiency of Nigeria.

\begin{tabular}{ll} 
Article History & ABSTRACT \\
\hline $\begin{array}{l}\text { Received: 23-07-2014 } \\
\text { Accepted: 28-08-2014 }\end{array}$ & $\begin{array}{l}\text { This study investigates the contributions of capital market and financially deepening to } \\
\text { economic growth in Nigeria over the period of 1981 to 2012. The analysis involves examining } \\
\text { the stochastic characteristics of each time series variable by testing their stationarity using } \\
\text { Augmented Dickey-Fuller (ADF) test and estimates the error correction mechanism model. } \\
\text { The study revealed that Stock Market Capitalization, Narrow Money Diversification (involving } \\
\text { credit to the private sector) and Interest Rate significantly impacted the promotion of } \\
\text { economic growth of the country during the period of study. Though, other measures of } \\
\text { liquidity represented by Financial Development (FID) and Monetization Ratio (MTR) were } \\
\text { not significant in explaining the trend in economic growth, they exhibited very strong } \\
\text { Capital market; }\end{array} \quad \begin{array}{l}\text { coefficients in the process. The study recommends that Government and other stakeholders } \\
\text { in the economy should take measures further to improve the liquidity of the financial market } \\
\text { to enhance overall economic efficiency in the country. In addition to proper monetary policy } \\
\text { Economicial growth. }\end{array}$ \\
management, the study further recommends that concrete steps be taken to improve the \\
activities of the Nigerian stock market.
\end{tabular}

JEL Classification:

E04; G02; F43.

DOI: http://dx.doi.org/10.18533/jefs.v2i03.69

(C) 2014 The Authors. This is an open access article under the terms of the Creative Commons Attribution License 4.0, which allows use, distribution and reproduction in any medium, provided the original work is properly cited.

\subsection{Introduction}

The objective of economic development constitutes a primal position in the task of Governance around the world. The financial sector plays a crucial role in the process of economic growth of any nation. The depth of the country's financial sector has been found to relate with the speed of economic progress. Analysts have observed that wellfunctioning capital markets increase economic efficiency, investment and growth. Capital market development is an important component of the financial sector development and supplements the role of the banking system in terms economic development. Long term capital is deemed crucial for economic development as evidenced by the positive relationship between long-term capital and economic growth (Demirguc and Levine, 1996). It is the responsibility of the capital market to attract funds for long-term capital for the economy at the right price. Specifically, capital markets assist in price discovery, liquidity provision, reduction in transactions costs, and risk transfer. They reduce information cost through generation and dissemination of information on firms leading to efficient markets in 
which prices incorporate all available information (Yartey and Adjasi, 2007; Garcia and Liu, 1999). Overall, stock markets provide market liquidity that enables implementation of long-term projects with long-term payoffs thereby promoting a country's economic growth. Moreover, efficient capital markets not only avail resources to investors, they also facilitate inflow of foreign financial resources into the domestic economy.

Financial deepening is like one of those strategies whose implementation can quicken the pace of development. However, the effect of this strategy needs to be determined and examined from time to time especially for developing economies. Financial deepening focuses more on the process of financial intermediation. Financial markets undertake this vital role of the intermediation process, by channeling funds from surplus units (savers) to deficit units (investors). When a country's process of financial intermediation is efficient and without repression, the outcome is usually a well-developed and functioning financial sector with the capacity to support economic growth. But where the contrary is the case, the result is an economy beset with "financial shallowness" which is a common problem infecting the growth of development economies (Goldsmith, 1969; Ghani, 1992). Developing Countries possess financial assets and instruments that are narrow, and this is condition is usually akin to shallow financial depth. This condition partly explains why countries in with shallow financial depth experience low or negative per capita income. Opinionating, Nnanna and Dogo (1998) said that financial deepening often refers to a state of an atomized financial system, meaning a financial system that is largely free from financial repression. Oloyede (1998) remarked. Thus, financial deepening is the outcome of accepting appropriate real finance policy such as relating real rate of return to real stock of finance. Where then do we place the Nigerian financial system on the barometer of financial repression and subsequently financial deepening?

It is instructive to note that the vibrant and unprecedented economic growth of the emerging markets of the subSaharan Africa (average 6.5\%), which became more glaring from early 2001, was however called to question in 2008, no thanks to the global economic and financial meltdown. With the near collapse of Nigerian stock market between 2008 and 2009, Nigeria like other sub-Saharan Africa counterparts, had a taste of the contagion of global economic and financial crises. Between 2008 and 2009, the Nigeria stock exchange lost almost 63\% of its market capitalization and $67.2 \%$ of her all share indexes. The cumulative loss till date (Nov 2012), stands in the neighbourhood N6 trillion. In fact, the performance of Nigerian stock market from 2008 till date has made nonsense of most known fundamental and technical analysis for equity investment. For instance in 2007, the market capitalization skyrocketed from N2900bn in 2005 to N13294.50bn in 2007. While new issues rose from N552.78bn to $\mathrm{N} 2400 \mathrm{bn}$. This phenomenal growth notwithstanding, the market capitalization represents only 28 percent of the GDP, compared with 167.1 per cent for South Africa, 50.7 percent for Zimbabwe and 130 percent for Malaysia. This indicates that the potentials for growth in the Nigerian market are still very enormous. (Ukeje, Kama, Eluemunor, 2007).

Many Nigerian's for numerous reasons are unbanked and lack access to formal financial services. The result of a survey conducted by Elfin Access in Nigeria in 2012 revealed that 34.9 million adults representing 39.7\% of the adults in the Country did utilize the services of formal financial institutions (Efina, 2012). Only 28.6 million adults in Nigeria access and utilize formal financial services and this represents $32.5 \%$ of the adult population. In addition, the survey by Efina (2012) also revealed that 23.0 million adults save at home. This means that a huge bulk of the country's currency circulates outside the formal financial sector. This poses real problems to the economy in terms of controlling liquidity and financial deepening process.

Given this background the key objectives of this research study are: (i) to examine the contribution of the Nigerian Capital market to the country's economic growth, (ii) to establish the impact of financial deepening on the Nigeria's economic growth, and (iii) to understand the combined impact of capital market and financial deepening on the Nigerian economic growth process. Therefore, the following hypothesis have been formulated for the study: (i) developments in the capital market have not made an impact on the country's economic growth process; (ii) financial deepening has not made significant impact on the Nigerian growth process (iii) developments in the capital market and financial deepening have jointly not significantly impacted on the Nigerian economic growth process.

The existing literature in this field of study so far has not separated the contributions of financial deepening variables and capital market variables in the analysis of contributions to the country's economic growth. This approach is expected to guide us in a better analysis of the Nigeria's financial markets and, therefore, position us to make improve recommendations on how to improve their contributions to the country's growth process.

The paper is divided into five sections; the first section gives a general introduction to the phenomenon of globalization and serves as background of the paper stating its problem and its objectives, hypotheses and justification. Section 2 looks into the review of existing related literature on the topic while section 3 presents the Analytical Framework. Section 4 discusses the presentation of results. Section 5 is the conclusions and policy recommendations 


\section{$2.0 \quad$ Review of literature}

The earliest establishment of the link between finance and growth in literature could be traced to the work of Schumpeter (1911) in which he contends that entrepreneurs require credit in order to finance the adoption of new production techniques with banks as key agents to facilitate financial intermediating activities. In this way, it is expected that a well-functioning banking system will provide intermediation services to productive entrepreneurial activities which will spur technological, innovative, and productive activities that increase real sector growth. Gurley and Shaw (1955), Goldsmith (1969) and Hicks (1969) have also argued along this line, positing that development of the financial system is crucial in stimulating economic growth and under-developed financial systems retard economic growth hence policies aimed at expanding the financial system should be formulated in order to foster growth. McKinnon (1973) and Shaw (1973) have also emphasized on the role of financial intermediaries and financial markets in the growth process. The McKinnon model assumes that the investment in a typical developing economy is mostly self-financed hence given its lumpy nature, investment cannot materialize unless sufficient saving is accumulated in the form of bank deposits (McKinnon, 1973). Also, Shaw (1973) has postulated that financial intermediaries promote investment and raise output growth through borrowing and lending. The result of such financial liberalization, Ang (2007) argues, will lead to increased output growth.

The capital market is no doubt pivotal to the level of development and growth of the economy. Chinwuba \& Amos, (2011) note that capital market is one of the major institutions that act in propelling a prostate economy through sustainable investments for growth and development. It is a complex institution imbued with inherent mechanism through which long-term funds of the surplus sectors of the economy are mobilized, harnessed and made available to deficit sectors of the economy (Nyong, 1997). The market deals on medium and long term securities. Activities in the capital market are good indicators of the direction of the national economy. Efficiency and effectiveness in the performance of the market is expected to translate into buoyancy in economic development.

Osaze and Anao, (1999) assert that capital market is the cornerstone of any financial system since it provides the funds needed for financing not only business and other economic institutions, but also the programmes of government as a whole. Ilaboya and Ibrahim, (2004) document that capital market functions as an economic barometer for galvanizing economic activities. Al-Faki, (2006) summarizes that the market covers the entire schedule that facilitate the buying and selling of securities.

The studies on stock market development and economic growth in developing countries have shown controversial results. Levine and Zervos (1996) examines whether there is a strong empirical association between stock market development and long-run economic growth. The study used pooled cross-country time-series regression of fortyone countries from 1976 to 1993 to evaluate this association. The study tow the line of Demirguc-Kunt and Levine (1996) by conglomerating measures such as stock market size, liquidity, and integration with world markets, into the index of stock market development. The growth rate of Gross Domestic Product (GDP) per capita was regressed on a variety of variables designed to control for initial conditions, political stability, investment in human capital, and macroeconomic conditions; and then include the conglomerated index of stock market development. The finding was that a strong correlation between overall stock market development and long-run economic growth exist. This means that the result is consistent with the theories that imply a positive relationship between stock market development and economic growth.

The study of Mahtadi and Agarwal (2001) covers many emerging markets over 21 years and finds that this relationship exists both directly and indirectly by boosting private investment behavior. In a similar study, Caporale and Soliman (2004) observe that an organized and managed stock market stimulate investment opportunities by recognizing and financing productive projects that lead to improved economic activity, mobilize domestic savings, capital allocation proficiency, and help to diversify risks, and facilitate the exchange of goods and services. Stock markets are expected to increase economic growth by increasing the liquidity of financial assets, make global and domestic risk diversification possible, promote wiser investment decisions and positively influence corporate governance practices by increasing shareholders' interest value.

Ted Arzarmi et al. (2005) examined the empirical association between stock market development and economic growth in India. The authors found no evidence of the association between the Indian stock market development and economic growth in the entire period they studied. Whereas the authors found support for the relevance of stock market development in economic development during pre-liberalization, they discovered a negative relationship between stock market development and economic development for the post-liberalization period.

Enisan and Olufisayo (2009) through autoregressive distributed lag (ARDL), evaluate the long-run relationship between stock market development and economic growth in seven of the Sub-Saharan African countries. The results indicate that stock market has a positive and significant impact on growth. Causality results indicate unidirectional causality from stock market development to economic growth for both South Africa and Egypt. While 
Cote D'Ivoire, Kenya, Morocco and Zimbabwe indicate bidirectional causality, Nigeria on the other hand shows weak evidence that growth causes the finance. Finally, Osinubi (1998) examines whether stock market promotes economic growth in Nigeria between the period 1980 and 2000. The study employed the Ordinary Least Squares (OLS) regression technique as the method of data estimation. The regression results confirm that there exist a positive relationship between the economic growth and the measures statistically insignificant. This in essence means that the effect of the stock market on economic growth is weak and insignificant considering the stock market development used. However, these relationships are statistically insignificant. This in essence means that the effect of the stock market on economic growth is weak and insignificant.

\subsection{Analytical framework}

In investigating the relationship between stock market performance and economic growth, we made use of the $\mathrm{Neo}=$ Classical Growth model, where rate of economic growth depends on the growth rate of (i) Capital Stock, K; (ii) Labour Supply, L; and (iii) Technological Progress over Time, (Dwivedi, 2008). The relationship between the national output and these variables are expressed in the form of a production function, thus:

$Y=f(K, L, T)$

The application of this model is however modified to represent the variables in our study and is accordingly specified as follows:

$\mathrm{EG}=\mathrm{f}(\mathrm{SMP}, \mathrm{TVS}, \mathrm{TLE}, \mathrm{FID}, \mathrm{MTR}, \mathrm{NMD}, \mathrm{INT})$

Where, EG (Economic Growth) is Gross Domestic Product (GDP), Stock Market Performance (SMP), Total Value of Shares Traded (TVS), Total Listing on the Exchange (TLE), Financial Development (FID), Monetization Ratio (MTR), Narrow Money Diversification (NMD), and Interest Rate (INT). We consider capital market variables as SMP, TVS and TLE; while, financial deepening variables as FID, MTR, NMD, and INT.

Rearranging equation 2 in line with the model, we have:

$G D P=\beta 0+\beta 1 M C A P+\beta 2 T V S+\beta 3 T L E+\beta 4 F I D+\beta 5 M T R+\beta 6 \mathrm{NMD}+\beta 7 I N T+\mu \ldots$.

Equation (3) is designed to measure the relationship that exists between Gross Domestic Product and other independent variables. This is to see how those explanatory variables influence Economic Growth in the economy. In line with a priori expectations, the expected signs of the coefficients are: $\beta 1>0 ; \beta 2>0 ; \beta 3>0 ; \beta 4>0 ; \beta 5>0$; $\beta 6>0 ; \beta 7<0$. The above sign $(>0)$ implies a positive relationship between GDP and the coefficients of the independent variable while $(<0)$ connotes a negative relationship.

Our Model for analysis is derived from equation (3) above. The Model contains GDP, Capital Market variables (MCAP, TVS and TLE) and Financial Deepening variables (FID, MTR, NMD and INT). Note that capital market variables are clear as specified since the figures for them can be obtained directly over the years. However, the financial deepening variables require further definitional analysis as follows:

Financial development (FID):

It is a measure of the increase in the volume of financial services of the banks, financial intermediaries, financial institutions and financial market, as demonstrated by credit to the private sector of the economy. Augusto de la Torre et al. (2006) noted that stock market development under globalization; whether the gain from reforms. The trio used F.D as one of the independent variables that determine G.D.P growth in the economy. They found that the financial development leads to growth.

FID $=$ Credit to Private Sector/GDP.

Where, FID = Financial Development and GDP $=$ Gross Domestic Product

Monetization ratio (MTR):

This ratio is computed as M2 divided by nominal GDP. It is sometimes referred to as the Broad Money Velocity was used by King and Levine (1993). It reflects the depth of the financial market relative to the overall economy. Increases in this ratio indicate further expansion in the financial sector relative to the rest of the economy. Thus:

$\mathrm{MTR}=\mathrm{M} 2 / \mathrm{GDP}$.

Where, MTR = Monetization Ratio, M2 = Total Monetary Liability (Broad Money), and GDP = Gross Domestic Product

Narrow money diversification (NMD): 
This is the ratio of demand deposits to the narrow money stock. Vogel and Buser (1976) argue that this measure represents the complexity, or sophistication of the financial market (primarily banks). The increase in this ratio implies a higher degree of diversification of financial institutions and greater availability or use of non-currency balances (bank deposits) in the transaction process. In this paper, we adopted narrow money stock denoted as M1. Therefore;

$\mathrm{NMD}=\mathrm{DD} / \mathrm{M} 1$

Where, NMD = Narrow Money Diversification, DD = Demand Deposit, and M1 = Money Supply.

Interest Rate (INT):

The annualized cost of credit or debt-capital and is computed as the percentage ratio of interest to the principal. The Monetary Authority determines it. In Nigeria, the interest rate which is determined by the Monetary Authority is referred to as the Monetary Policy Rate.

Given the variables definitions, it must be mentioned that the figures for GDP, MCAP, TVS and TLE are obtained in Millions while figures for FID, MTR, NMD and INT are in rates. Therefore, to obtain realistic results for our model of analysis, we would transform the model by taking logarithm of the variables in Millions. Therefore, our equation 3 becomes transformed to equation seven below:

$\operatorname{LogGDP}=\alpha_{0}+\alpha_{1} \operatorname{LogMCAP}+\alpha_{2} \operatorname{LogTVS}+\alpha_{3} \operatorname{LogTLE}+\alpha_{4}$ FID $+\alpha_{5} \mathrm{MTR}+\alpha_{6} \mathrm{NMD}+\alpha_{7} \mathrm{INT}+\mu \ldots$.

\subsection{Results and analysis}

\subsection{Estimation strategy}

The estimation technique consists of four steps procedures. The first step is the unit root test which involves the determination of the stationarity property of the time series variables, using the Augmented Dickey-Fuller (ADF) test statistics for unit root (Dickey \& Fuller, 1979). The second is impact estimation, using Least Squares multiple regression methods (including a constant term) is run over the sample period 1981-2011. The third is cointegration test to establish whether the time series variables have long-run equilibrium relationship. The fourth step involves testing for Error Correction Mechanism. If the cointegration test shows that the variables have long-run equilibrium relationship, then, it is a sufficient condition for an ECM formulation. If variables are non-stationary at level, but cointegrated, their dynamic relationships will be specified correctly by an error correction model (Granger and Engle, 1987).

\subsection{Unit root test}

The unit root test is necessary because research has shown that non-stationary data leads to spurious regression, which may affect in determining the cointegration relation in the long run. A summary of the results of the tests is presented in Table 1 below.

From the ADF test statistics, the results in Table 1 show that LOGGDP, LOGMCAP, LOGTVS, LOGTLE, FID, MTR, NMD and INT were integrated at order one, that is I(1), or they became stationary at first difference. Comparing the variables levels with their first difference (the ADF unit root test statistic) and various probabilities, the test statistics show that the variables are integrated at order of one. All the variables were statistically significant at $1 \%$, $5 \%$ and $10 \%$ critical values in first difference.

\begin{tabular}{lccc}
\hline \multicolumn{4}{c}{ Table 01: ADF Fisher unit root test result } \\
\hline Variables & $\mathrm{I}()^{*}$ & ADF T-Stat & Max Lag \\
\hline D(LOGGDP) & $\mathrm{I}(1)$ & $-4.697^{* * *}$ & 1 \\
D(LOGMCAP) & $\mathrm{I}(1)$ & $-4.342^{* * *}$ & 1 \\
D(LOGTVS) & $\mathrm{I}(1)$ & $-4.665^{* * *}$ & 1 \\
D(LOGTLE) & $\mathrm{I}(1)$ & $-5.398^{* * *}$ & 1 \\
FID & $\mathrm{I}(1)$ & $-4.657^{* * *}$ & 1 \\
MTR & $\mathrm{I}(1)$ & $-6.258^{* * *}$ & 1 \\
NMD & $\mathrm{I}(1)$ & $-4.914^{* * *}$ & 1 \\
INT & $\mathrm{I}(1)$ & $-8.796^{* * *}$ & 1 \\
\hline Note: $* * *, * *$ & and $*$ referrers significance at $1 \%, 5 \%$, and $10 \%$ respectively. \\
\hline
\end{tabular}




\subsection{The estimated model}

The regression equation of 07 was designed to measure the relationship that exists between Gross Domestic Product and other independent variables. This is to see how those explanatory variables influence Economic Growth in the economy. In line with a priori expectations, the expected signs of the coefficients are: B1<0; B2< 0; B3>0; B4> 0; B5 $>0$. The above sign $(>0)$ implies a positive relationship between GDPR and the coefficients of the independent variables.

\begin{tabular}{lrrrr}
\hline \multicolumn{5}{c}{ Table 02: Result of multiple regression } \\
\hline Variable & $\beta \mathrm{i}$ & Std. Error & t-Statistic & Prob. \\
\hline$\alpha$ & 5.793 & 2.539 & 2.282 & 0.032 \\
LOGMCAP & 0.670 & 0.118 & 5.679 & 0.000 \\
LOGTVS & 0.134 & 0.074 & 1.803 & 0.084 \\
LOGTLE & -0.133 & 0.482 & -0.275 & 0.786 \\
FID & -3.180 & 2.011 & -1.581 & 0.127 \\
MTR & 3.050 & 1.641 & 1.859 & 0.075 \\
NMD & -2.399 & 0.756 & -3.171 & 0.004 \\
INT & 2.462 & 0.888 & 2.772 & 0.011 \\
\hline R-squared & 0.896 & Mean dependent var & 14.246 \\
Adjusted R-squared & 0.845 & S.D. dependent var & 2.319 \\
S.E. of regression & 0.171 & Akaike info criterion & -0.478 \\
Durbin-Watson stat & 1.948 & Schwarz criterion & -0.112 \\
\hline
\end{tabular}

Thus, the estimated models can be written as:

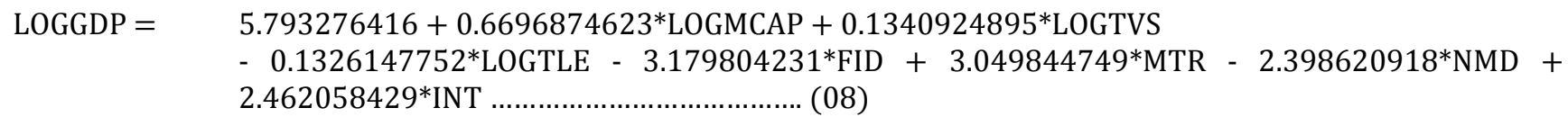

A quick view of the result in table 2 shows that GDP is positively related to LOGMCAP, LOGTVS, MTR AND INT while LOGTLE, FID and NMD are negatively related to LOGGDP. The R-squared and Adjusted R-squared indicated a good fit. About $89 \%$ of the variation in GDP is explained by the variation in the independent variables.

From the estimated result, it is obvious that if Log of Market Capitalisation (LOGMCAP), Log of Total Value of Shares Traded (LOGTVS), Monetisation Ratio (MTR) and Interest Rate (INT) are increased by 1\%, GDP will increase by $0.66 \%, 0.13 \%, 3.05 \%$, and $2.46 \%$ respectively. The result also shows that if Log of Total Listing of Equity (LOGTLE), Financial Development (FID), and Narrow Money Diversification (NMD) are increased by 1\%, GDP will decrease by $13 \%, 3.18 \%$ and $2.40 \%$ respectively.

To test our hypothesis we used the probability (p-value) of observing the t-statistic given that the coefficient is equal to zero. Only three independent variables are statistically significant in explaining the variation in GDP at 5\% and $1 \%$ levels of significance. The variables are Log of Market Capitalisation (LOGMCAP), Narrow money Diversification (NMD) and Interest Rate (INT).

The variable with the strongest significant impact on GDP is Interest Rate with a positive coefficient of 2.46. This is closely followed by Narrow Money Diversification (NMD) with a negative coefficient of 2.40. NMD refers to credit advanced to Private Sector by Banks in the economy. With negative and positive coefficients of 3.17 and 3.05 Financial Development and Monetisation Ratio indicates very strong relationship with GDP while noting that the coefficients are statistically insignificant. The variable with the weakest and most-insignificant impact on GDP is Log of Total number of securities listed on an exchange (TLE). The value of Durbin-Watson Statistic (1.95) indicates the absence of autocorrelation in the analyzed data. The value of F-Statistic is 808.14. An analysis of the probability value for F-Statistic (Prob F-Stat $=0.0000$ ) indicates that entire regression equation is significant at both $1 \%$ and $5 \%$ levels of significance. The model is a good fit.

To effectively test the joint significance of both financial deepening variables and capital market variables in explaining the variation in GDP we employed Wald Coefficient test statistic referenced in Appendix 1. From the result, we observe that the combined impact of the financial deepening variables showed that F-Statistic of 7.95 and Chi-Square statistic showed 28.84. But the Probability results showed 0.007 indicating that the combined impact of Financial deepening variables (FIN, MTR, NMD and INT) on GDP during the period of analysis are statistically significant (at both $5 \%$ and 1\%). The Wald test result on capital market variables (LOGMCAP, LOGTVS and LOGTLE) shows that F-statistic is 626.71, and Chi-Square is 1880.13 . However, the Probability results showed 0.000 
indicating that the combined impact of Capital Market variables LOGGDP during the period of analysis are statistically significant (at both $5 \%$ and $1 \%$ ).

\subsection{Cointegration test}

The unit root test earlier conducted showed that the variables are stationary at first difference. Stationarity of the residuals is potent evidence that there is evidence of convergence to long-run equilibrium among the integrated variables. Now we wish to test whether the variables are cointegrated over the sample period and if so, what the cointegrating relation is. To determine the number of significant co integration relationships, we use the Johansen's co-integration test that yields the log likelihood estimates for the unconstrained co-integration vectors.

\begin{tabular}{|c|c|c|c|c|}
\hline \multicolumn{5}{|c|}{ Table 03: Johansen cointegration test } \\
\hline Hypothesized No. of CE(s) & Eigenvalue & Trace Statistic & Critical Value & Prob.** \\
\hline None * & 0.921 & 303.181 & 187.470 & 0.000 \\
\hline At most $1^{*}$ & 0.884 & 226.750 & 150.558 & 0.000 \\
\hline At most $2 *$ & 0.787 & 162.001 & 117.708 & 0.000 \\
\hline At most $3 *$ & 0.781 & 115.477 & 88.803 & 0.000 \\
\hline At most $4^{*}$ & 0.636 & 69.844 & 63.876 & 0.014 \\
\hline At most 5 & 0.433 & 39.461 & 42.915 & 0.106 \\
\hline At most 6 & 0.323 & 22.415 & 25.872 & 0.126 \\
\hline At most 7 & 0.299 & 10.691 & 12.517 & 0.099 \\
\hline
\end{tabular}

Note: Trace test indicates 5 cointegrating eqn(s) at the 0.05 level. * denotes rejection of the hypothesis at the 0.05 level; **MacKinnon-Haug-Michelis (1999) p-values

The results of the co-integration in table 3 confirmed that there are five co-integration relationships among the variables included in the model. Specifically, the result of the co-integration test suggests that the variables have long-run equilibrium relationship with each other. This evidence of co-integration among the variables rules out spurious correlations and applies that five directions of influence can be established among the variables. It is important to note that the existence of co-integration vectors among a group of variables may not imply that there is causal influence between pairs of variables in the model of co-integration test. The presence of a co-integrating relation forms the basis of the error correction specification. The cointegration term is known as an error correction term since the deviation from long-run equilibrium is corrected gradually through a series of partial short-run adjustments Granger and Engle (1987).

\subsection{Error correction model and long-run behavior of the model}

A vector error correction (VEC) model is a restricted VAR designed for use with non-stationary series that are known to be cointegrated. The VEC has cointegration relations built into the specification so that it restricts the long-run behavior of the endogenous variables to converge to their cointegrating relationships while allowing for short-run adjustment dynamics. Our analysis of table 1 shows that since the variables are non-stationary at levels but become stationary after first difference, the variables in the model are cointegrated. Given the situation, their dynamic relationships must be specified by the error correction model (ECM) in order to capture both the short-run and long-run relationships. The Error Correction for the long run Economic Growth equation is written below:

$$
\begin{gathered}
\mathrm{D}(\text { LOGGDP })=\begin{array}{r}
-0.217 *(\text { LOGGDP }(-1)-8.915-0.219 * \text { LOGMCAP }(-1)+0.400 * \text { LOGTVS }(-1) \\
+0.768 * \operatorname{LOGTLE}(-1)+3.615 * \text { FID }(-1)-6.605 \operatorname{MTR}(-1)+0.699 * \operatorname{NMD}(-1)
\end{array} \\
-5.708 * \text { INT }(-1)) \ldots \ldots \ldots \ldots \ldots \ldots \ldots . .(09)
\end{gathered}
$$

The equation above depicts the Error Correction Mechanism (ECM) of our Model (see Appendix 2). It implies that the long run adjustment coefficient of the dependent variable (LOGGDP) is -0.22 . The value is negative and statistically significant in conformity with an effective error correction model. It indicates that the speed of annual (short-run) adjustments of LOGGDP is $22 \%$ to long run deviations from equilibrium. The long-run intercept term for the model is negative with 8.92. The Error Correction Equation also depicts that the coefficients of LOGMCAP, MTR and INT are negative in adjusting to the long run disequilibrium given by the ECM value $(-0.58)$. The coefficients of LOGTVS, LOGTLE, FID and NMD are positive in serving the same purpose. However, the result shows that LOGMCAP, LOGTVS and INT are statistically significant, therefore, more meaningful in our analysis while trying to determine the growth rate of LOGGDP in the long run.

\subsection{Policy recommendation for Nigeria}

This research study attempts to investigate the relationship between capital market, financial deepening and economic growth. The deductions that could be made from the empirical findings are predicted on the sizes and 
magnitude of the slope coefficient. It was revealed that Market Capitalisation, Narrow Money Diversification (credit to a private sector) and Interest Rate significantly impacted the promotion of economic growth of the country during the period of study. Though, other measures of liquidity represented by Financial Development (FID) and Monetisation Ratio (MTR) were not significant in explaining the trend in economic growth, they exhibited very strong coefficients in the process. Overall, the Wald Coefficient Test revealed that jointly, the proxies for both Capital Market and Financial Deepening (separated) are significant in explaining the trend in economic growth.

In the light of the above, the Government and other stakeholders in the economy should put measures that are directed at: First, improve liquidity of the economy and further expand the financial services sector. Specific measures along this line would involve further monetization of the economy to involve the huge sector that does not utilize the financial services provided by the money and capital markets. The process may require more enlightenment of the middle and lower cadre of the Nigerian people and spread of Branches of financial institutions in the country to areas without access to banking services. Second, the role of credit to the growth of the economy is well-exhibited by the significant impact of narrow money diversification (NMD) on economic growth (GDP) in our analysis. It means that a further advancement of properly structured loans and advances to the key producing sectors of that would improve the size of the country's GDP. Third, improvements in capital market activities. This can be handled by improving the enabling environment to make the Nigerian stock market globally competitive and improve the architecture to enhance hitch free trading and reporting. Regulatory activities for trading should also be properly supervised while emphasizing professionalism on the part of market operators and stock brokers. Government policies should also be geared towards increasing money supply and improving the liquidity of the capital market as this will enhance overall economic efficiency and increase investor confidence in capital market activities.

\subsection{Conclusion}

The broad focus of this paper was to identify, within an empirical framework, the proportionality relationship between economic growth and proxies for capital market and financial deepening of the Nigerian economy. We developed a multiple regression equation model, which focuses explicitly on the impact of capital market and financial deepening proxies on the country's economic growth. The econometric model that is adopted was used to regress the impact of these factors on Nigeria's economic growth that is proxied by GDP. The results and analysis of our research findings are predicated on the values of the different parameters of dependent variables.

This paper provided evidence showing that activities in the Nigeria's Capital Market have impact on the Country's economic growth. Financial deepening variables also have impacted on the Country's GDP. Specifically, GDP is significantly impacted by Growth in Market Capitalisation (MCAP), Narrow Money Diversification (NMD) and interest rate (INT). The paper recommends that Government and stake holders in the economy should come up with measures to improve liquidity in the economy. Expansion of financial services to deficient locations is emphasized along with the extension of credit facilities to key producing sectors of the economy. The paper also recommends that there should be concrete improvements in the activities of the Nigerian capital market. Laws should be enacted to make the Nigerian stock market more globally competitive, and there should be proper regulation of the activities of market operators.

\section{References}

Al-FakI, M. 2006. The Nigerian capital market and socioeconomic development. 4th Distinguished Faculty of Social Science Public Lecture, 9-16.

Ang, J. B., \& McKibbin, W. J. 2007. Financial liberalization, financial sector development and growth: evidence from $\begin{array}{lllll}\text { Malaysia. Journal of } & \text { Development }\end{array}$ http://dx.doi.org/10.1016/j.jdeveco.2006.11.006

Caporale, G. M., Howells, P. G., \& Soliman, A. M. 2004. Stock market development and economic growth: the causal linkage. Journal of Economic Development, 29(1): 33-50.

Chinwuba, O., \& Amos, O. A. 2011. Stimulating Economic Development through the Capital Market. The Nigerian Experience. JORIND, 9(2).

De la Torre, A., Gozzi, J. C., \& Schmukler, S. L. 2007. Stock market development under globalization: Whither the gains from reforms?. Journal of Banking \& Finance, 31(6): 1731-1754. http://dx.doi.org/10.1016/j.jbankfin.2006.11.008

Demirgue Kunt, A. and R. Levine 1996. Stock market, corporate finance and economic growth: an overview. The World Bank Review, 10(2): 223-239. http://dx.doi.org/10.1093/wber/10.2.223

Dwivedi, D.N 2008. Managerial Economics; New Delhi: Vikas Publishing House

Efina.org, http://www.efina.org.ng/about-us/financial-inclusion/ 
Engle, R.F. and C.W.J. Granger 1987. Cointegration and error correction: representation, estimation and testing. Econometrica, 55: 251-276. http://dx.doi.org/10.2307/1913236

Enisan, A. A. and A.O Olufisayo 2009. Stock market development and economic growth: evidence from seven subSahara African countries. Journal of Economics and Business, 61: 162-171. http://dx.doi.org/10.1016/j.jeconbus.2008.05.001

Goldsmith, R.W. 1969. Financial Structure, and Development, Yale University Press: New Haven.

Gurley J.G and E.S Shaw 1955. Financial aspects of economic development. American Economic Review, 45:515-538

Hicks, J.A 1969. A theory of economic history, Oxford: Clarendon Press

Ilaboya, O.J. and Ibrahim, S. 2004. Impact of stock market performance on the level of economic activities: Evidence from Nigerian stock market. Nigerian journal of business administration, Vol.6 No 1.

King R.G and R. Levine, 1993. Finance and growth: Schumpeter might be right. Quarterly Journal of Economics, 108:715-735. http://dx.doi.org/10.2307/2118406

Levine and Zervos 1996. Stock market development and long-run growth. The World Bank Economic Review, 10(3): $323-339$.

Mahtadi, H. and Agarwal, S., 2001. Stock market development and economic growth: evidence from developing countries. http://www.articlesbase.com /finance- articles/stock-market-developmentandeconomic-growthevidence-from- underdevelopednation- Nepal-1096815.html

McKinnon, R., 1973. Money and capital in economic development, Washington, D.C.: Brookings Institution

Nnanna, J. \& Dogo, M., 1999. Structural reform, monetary policy and financial deepening: the Nigeria experience: Mimeo

Nyong, M. O. 1997. Capital market development and long-run economic growth: theory, evidence and analysis. First Bank Review :13-38.

Oloyede, A., 1998. The financial system's role in resource mobilization and investment: an analysis of financial deepening in Nigeria's financial sector. In the Dynamics of Managing the Nigerian Financial System in the 21st Century. A Publication of the Central Bank of Nigeria.

Osaze, B.E. \& Anao, A.R., 1999. Managerial Finance. Benin City: UNIBEN Press.

Osinubi, Tokunbo S., 1998. Stock market development and long-run growth in Nigeria. Unpublished M.Sc. Economics Dissertation, University of Ibadan Nigeria. Presented at 3rd Distinguished Faculty of Social Science Public Lecture Series, University of Ibadan

Schumpeter, J.A, 1911. The theory of economic development. Oxford: Oxford University Press

Shaw, E., 1973. Financial deepening in economic development. Oxford: Oxford University Press Journal of Development Economics, September/October, 1-24

Ted, A., Lazar, D., \& Jeyapaul, J., 2005. Is the Indian stock market a casino?. Journal of Business and Economic Research, 3(4): 63-72.

Ukeje EU, Kama U, Eluemunor, 2007. A review of the Nigerian capital market in capital market dynamics in Nigeria: structure, transaction cost and efficiency 1980-2006. A Publication of the Central Bank of Nigeria.

Vogel R. and S. Buser 1976. Inflation, financial repression, and capital formation in Latin America in Money and Finance in Economic Growth and Development. Ed, R. McKinnon, New York: Marcel Dekker, Inc.

Yartey C.O. and Adjasi C.K., 2007. Stock market development in sub Saharan Africa: critical issues and challenges. International Monetary Fund working paper No. wp/07/209.

\section{Appendix 01: Wald coefficient test}

\begin{tabular}{|c|c|c|c|c|c|c|c|}
\hline \multicolumn{4}{|c|}{ CAPITAL MARKET VARIABLES } & \multicolumn{4}{|c|}{ FINANCIAL DEPEENING VARIABLES } \\
\hline Test Statistic & Value & $\mathrm{df}$ & Prob. & Test Statistic & & $\mathrm{df}$ & Prob. \\
\hline F-statistic & 626.71 & $(3,24)$ & 0.000 & F-statistic & & $(3,24)$ & 0.007 \\
\hline Chi-square & 1880.13 & 3 & 0.000 & Chi-square & & 3 & 0.000 \\
\hline \multicolumn{8}{|c|}{ Null Hypothesis Summary } \\
\hline \multicolumn{2}{|c|}{ Normalized Restriction $(=0)$} & Value & Std. Err. & \multicolumn{2}{|c|}{ Normalized Restriction $(=0)$} & Value & Std. Err. \\
\hline $\mathrm{C}(2)$ & LOGMCAP & 0.669 & 0.117 & $\mathrm{C}(5)$ & FID & -3.179 & 2.010 \\
\hline $\mathrm{C}(3)$ & LOGTVS & 0.134 & 0.074 & $\mathrm{C}(6)$ & MTR & 3.049 & 1.640 \\
\hline \multirow[t]{2}{*}{$\mathrm{C}(4)$} & LOG TLE & -0.132 & 0.482 & $\mathrm{C}(7)$ & NMD & -2.398 & 0.756 \\
\hline & & & & $\mathrm{C}(8)$ & INT & 2.462 & 0.888 \\
\hline
\end{tabular}

Note: Restrictions are linear in coefficients. 
$\mathrm{D}($ LOGGDP $)=\mathrm{C}(1) *($ LOGGDP $(-1)-0.2191144118 *$ LOGMCAP $(-1)-0.4003384731 *$ LOGTRADG $(-1)$

$0.7684554124 *$ LOGTLE $(-1)+3.614986651 *$ FID $(-1)-6.604877693 *$ MTR $(-1)$

$0.6994782486 \quad * N M D(-1)-5.708437143 * \operatorname{INT}(-1)-8.914839977)$

$+$

$+\mathrm{C}(2) * \mathrm{D}(\operatorname{LOGGDP}(-1))$

$+\mathrm{C}(3) * \mathrm{D}(\operatorname{LOGMCAP}(-1))+\mathrm{C}(4) * \mathrm{D}($ LOGTVS $(-1))$

$+\mathrm{C}(7) * \mathrm{D}(\mathrm{MTR}(-1))+\mathrm{C}(8) * \mathrm{D}(\mathrm{NMD}(-1))$ $+\mathrm{C}(9)^{*} \mathrm{D}(\mathrm{INT}(-1))+\mathrm{C}(10)$ $+\mathrm{C}(5) * \mathrm{D}(\operatorname{LOGTLE}(-1))+\mathrm{C}(6) * \mathrm{D}(\mathrm{FID}(-1))$

Std. Error

0.120047

t-Statistic

Prob.

C(1)

$-0.217368$

0.252239

1.810690

0.0352

$\mathrm{C}(2)$

0.020220

0.164253

0.080163

0.9369

$\mathrm{C}(3)$

0.537295

0.078401

3.271142

0.0038

C(4)

$-0.237335$

0.479631

$-3.027192$

0.0067

C(5)

0.458186

2.178629

0.955289

0.3508

C(6)

2.438575

1.957491

1.119316

0.2763

$-0.034211$

$-0.017477$

0.9862

$\mathrm{C}(8)$

$-1.047194$

0.638638

$-1.639730$

0.1167

1.888486

0.783177

2.411316

0.0256

$\mathrm{C}(10)$

0.159350

0.056058

2.842604

0.0101

R-squared

0.571499

Mean dependent var

0.223897

Adjusted R-squared

0.378673

S.D. dependent var

0.174152

S.E. of regression

0.137274

Akaike info criterion

$-0.872477$

Log likelihood

23.08716

Durbin-Watson stat

2.109284 